\title{
Identifikasi Peran Kelompok Tani sebagai Unit Produksi dalam Mendukung Pengembangan Usaha Unit Pengolahan Pupuk Organik (UPPO)
}

\author{
Asih Farmia ${ }^{1 *}$ \\ ${ }^{1}$ Politeknik Pembangunan Pertanian Yogyakarta Magelang \\ *Corresponding author: farmiaasih@gmail.com
}

\begin{abstract}
Abstrak
Tujuan dari penelitian ini adalah untuk mengetahui peran kelompok tani sebagai wahana produksi dalam rangka mendukung produksi pengolahan pupuk oganik dan mengetahui tingkat minat petani dalam mengolah pupuk organik melalui kegiatan UPPO. Penelitian ini dilaksanakan pada Bulan Maret sampai Bulan Juni, Desa Widodomartani, Kecamatan Ngemplak, Kabupaten Sleman, DI Yogyakarta. Penentuan Lokasi dilakukan secara purposive karena desa mempunyai cukup banyak petani ternak dengan jumlah ternak sapi 698 ekor, kambing 895 ekor, ayam 2654 ekor, dan luas lahan pertanian dengan irigasi teknis 378 ha. Sedangkan Kelompok Tani Mekar dipilih secara purposive karena sudah mendapatkan bantuan UPPO dari pemerintah. Teknik penentuan sampling dilakukan dengan Teknik Non Probability Sampling yaitu sampling jenuh dimana jumlah sampel sebanyak 29 orang petani. Analisis data dengan menggunakan analisis deskriptif dan pengukuran peran kelompok petani serta minat petani dengan Skala Likert. Hasil analisis data menunjukkan peran kelompok tani masuk dalam kategori berperan sebagai wahana produksi dalam mendukung pengembangan UPPO sebagai unit usaha dengan jawaban rata-rata 2,69 dan presentasenya 67,33 $\%$ dan minat petani dalam mengolah pupuk organik melalui kegiatan UPPO masuk dalam kategori minat dengan jawaban rata-rata 2,45 dan persentasenya $62,79 \%$. Untuk dapat lebih meningkatkan peran kelompok tani, dan minat peyani dapat dilakukan dengan kegiatan pendampingan dari pembina untuk menjalin kerjasama kemitraan dengan pihak lain dalam bidang pemasaran pupuk organik sehingga kelompok tani diharapkan mampu berperan lebih baik lagi dalam mengembangkan produksi pupuk organik yang berorientasi pasar.
\end{abstract}

Kata kunci: Identifikasi peran, Kelompok tani, Pengembangan usaha, Unit produksi

\begin{abstract}
The purpose of this study was to determine the role of farmer groups as a production unit in order to support the production of organic fertilizer processing and to determine the level of interest of farmers in processing of organic fertilizers through UPPO activities. This research was conducted from March to June, Widodomartani Village, Ngemplak Sub District, Sleman Regency, Yogyakarta Special Region. Location determination was carried out purposively because the village has quite a number of livestock farmers with 698 cattle, 895 goats, 2654 chickens, and an area of agricultural land with technical irrigation of 378 ha. Meanwhile, the "Mekar" Farmers Group was chosen purposively because it had received UPPO assistance from the government. The sampling technique was determined using the Non Probability Sampling technique, namely saturated sampling where the number of samples was 29 farmers. Data analysis using descriptive analysis and measuring the role of farmer groups and farmers' interests with a Likert Scale. The results of data analysis show that the role of farmer groups is included in the category of acting as a unit for production in supporting the development of UPPO as a business unit with an average answer of 2.69 and the percentage is $67.33 \%$ and the interest of farmers in processing organic fertilizer through UPPO activities is included in the category of interest with the average answer is 2.45 and the percentage is $62.79 \%$. To be able to further increase the role of farmer groups, and the interest of service providers can be carried out with mentoring activities from supervisors to establish partnerships
\end{abstract}


Prosiding Seminar Nasional Pembangunan dan Pendidikan Vokasi Pertanian

Politeknik Pembangunan Pertanian Manokwari, 31 Juli 2021

e ISSN : 2774-1982

DOI: https://doi.org/10.47687/snppvp.v2i1.174

with other parties in the field of marketing organic fertilizers so that farmer groups are expected to be able to play a better role in developing market-oriented organic fertilizer production.

Keyword: Business development, Farmer groups, Identification of roles, Production units

\section{PENDAHULUAN}

Sektor pertanian mempunyai peranan strategis terutama sebagai penyedia pangan rakyat Indonesia, berkontribusi nyata dalam penyediaan bahan pangan, bahan baku industri, bioenergi, penyerapan tenaga kerja yang akan berdampak pada penurunan tingkat kemiskinan dan menjaga pelestarian lingkungan. Untuk mewujudkan kedaulatan dan kemandirian pangan diperlukan pelaku utama dan pelaku usaha profesional, andal, berkemampuan manajerial, kewirausahaan dan organisasi bisnis. Oleh karena itu, pelaku utama dan pelaku usaha mampu membangun usahatani yang berdaya saing dan berkelanjutan sehingga dapat meningkatkan posisi tawarnya. Untuk itu, kapasitas dan kemampuan pelaku utama dan pelaku usaha terus ditingkatkan, salah satunya melalui penyuluhan dengan pendekatan pembinaan kelembagaan petani yang mencakup penumbuhan dan pengembangan kelembagaan petani, sehingga petani dapat berkumpul untuk menumbuhkembangkan kelembagaannya menjadi Kelembagaan Ekonomi Petani (KEP) yang berdaya saing tinggi, produktif, menerapkan tata kelola berusaha yang baik, dan berkelanjutan (Permentan No. 67).

Dalam rangka mengembangkan pertanian organik, pemerintah melalui Kementerian Pertanian memberikan bantuan Unit Pengolah Pupuk Organik (UPPO) kepada beberapa kelompok tani. Adapun tujuan UPPO diantaranya adalah menyediakan fasilitas terpadu pengolahan bahan organik (jerami, sisa tanaman, limbah ternak, sampah organik) menjadi kompos (pupuk organik) dan mengoptimalkan pemanfaatan limbah kotoran hewan yang dimiliki kelompok peternak sebagai bahan baku kompos atau pupuk organik (Pedoman teknis UPPO, 2015). Anggota kelompok tani yang telah mendapatkan bantuan UPPO, melakukan kegiatan pengolahan pupuk organik dengan fasilitasi yang telah didapatkan dari bantuan UPPO.

Penyaluran bantuan oleh Kementerian Pertanian berupa Unit Pengolahan Pupuk Organik (UPPO) diharapkan dapat meningkatkan partisipasi petani untuk memanfaatkan limbah pertanian di sekitarnya menjadi pupuk organik (Sardjono dkk, 2012). Keberadaan UPPO di pedesaan ini memerlukan perhatian dan dukungan dari pihak-pihak terkait seperti pemerintah daerah setempat dan swasta sehingga UPPO dapat berfungsi secara optimal, 
Prosiding Seminar Nasional Pembangunan dan Pendidikan Vokasi Pertanian

Politeknik Pembangunan Pertanian Manokwari, 31 Juli 2021

e ISSN : 2774-1982

DOI: https://doi.org/10.47687/snppvp.v2i1.174

dan mencapai tujuan yang diharapkan. Menurut Permentan Nomor 67 tahun 2016, kelompok tani dapat juga berfungsi sebagai unit produksi. Kelompok tani yang mendapatkan bantuan UPPO diharapkan mampu berperan dalam mengembangkan produksi melalui UPPO sebagai suatu usaha.

Petani mempunyai peranan penting dalam pembangunan pertanian. Petanilah yang melakukan kegiatan memelihara tanaman serta menentukan seperti apa usahataninya harus dimanfaatkan (Mosher, 1985). Dari pengamatan di lapangan, pengolahan pupuk organik belum diarahkan ke suatu usaha yang berorientasi pasar dan masih bersifat lokal setempat dimana pupuk organik masih di produksi dalam skala kecil yang digunakan oleh anggota kelompok tani sendiri untuk budidaya padi dan juga dipasarkan jika ada pesanan dari luar dalam hal ini kelompok tani diharapkan mampu berperan dengan baik dalam mengembangkan produksi pupuk organik yang berorientasi pasar. Penelitian bertujuan untuk mengetahui peran kelompok tani sebagai wahana produksi dalam rangka mendukung produksi pengolahan pupuk oganik. Penelitian juga bertujuan untuk mengetahui tingkat minat petani dalam mengolah pupuk organik melalui kegiatan UPPO.

\section{METODE}

\section{Metode Penentuan Lokasi Penelitian}

Penentuan lokasi penelitian dilakukan secara purposive atau secara sengaja yaitu di Desa Widodomartani, Kecamatan Ngemplak, Kabupaten Sleman dari Bulan Maret sampai bulan Juni 2021. Hal ini dilakukan berdasarkan pertimbangan bahwa Desa Widodomartani merupakan salah satu desa yang cukup banyak mempunyai petani ternak dengan jumlah ternak ternak sapi 698 ekor, kambing 895 ekor, ayam 2654 ekor, dan luas lahan pertanian dengan irigasi teknis 378 ha (Profil Desa, 2019).

\section{Metode Penentuan Responden}

Metode yang digunakan untuk menentukan sampel secara purposive (sengaja) karena Kelompok Tani Mekar telah mendapatkan bantuan UPPO dari Kementerian Pertanian. Untuk teknik penentuan sampling dengan Teknik Non Probability Sampling yang dipilih yaitu dengan sampling jenuh yaitu dimana metode penarikan sampel dengan teknik ini bila semua anggota populasi dijadikan sebagai sampling. Hal ini sering dilakukan apabila jumlah populasi kecil, kurang dari 30 orang (Supriyanto dan Machfudz, 2010), adapun jumlah sampling sebanyak 29 orang. 
Prosiding Seminar Nasional Pembangunan dan Pendidikan Vokasi Pertanian

Politeknik Pembangunan Pertanian Manokwari, 31 Juli 2021

e ISSN : 2774-1982

DOI: https://doi.org/10.47687/snppvp.v2i1.174

\section{Metode Pengumpulan Data}

Data yang digunakan dalam penelitian terdiri dari dari primer data sekunder. Data primer didapatkan dari survey dengan menggunakan teknik pengumpulan data yaitu menggunakan kuesioner serta dilakukan wawancara kepada responden sedangkan data sekunder didapatkan kantor desa, kecamatan dan jurnal terdahulu serta literatur lain yang terkait.

\section{Metode Analisis Data}

1. Untuk menguji permasalahan yang pertama dilakukan dengan metode analisis deskriptif dengan menggunaan angket tertutup, Analisis Deskriptif yaitu menjelaskan dan menggambarkan keadaan fenomena yang terjadi di daerah penelitian serta untuk mengetahui peran kelompok tani sebagai wahana produksi dalam rangka mendukung produksi pengolahan pupuk oganik. Pengukuran dilakukan dengan skala Likert dengan empat kategori kemudian diberikan skor dari angka 1 sampai dengan 4 yaitu:

Skor 4: Sangat berperan

Skor 3: Berperan

Skor 2: Kurang berperan

Skor 1: Tidak berperan

Menurut Sugiyono (2009) pengukuran dilakukan dengan skala Likert, Skala likert adalah suatu skala psikometrik yang umum digunakan dalam kuisioner dan menyatakan skala yang paling banyak digunakan untuk riset berupa survei.

Dalam mengukur peran kelompok tani dapat dikelompokkan sebagai berikut:

Skor tertinggi $=4$ (dengan asumsi $100 \%)$

Skor terendah $=1($ dengan asumsi $25 \%)$

Interval kelas $=\underline{\text { skor tertinggi }- \text { skor terendah }}$ Jumlah kelas

Interval kelas $=\underline{100 \%-25 \%}$

Interval kelas $=18,75$

Dari interval kelas tersebut diperoleh range skor sebagai klasifikasi penilaian minat pemuda terhadap agribisnis padi sawah sebagai berikut:

Skor $81,26 \%-100 \%=$ kategori sangat berperan

Skor $62,51 \%-81,25 \%=$ kategori berperan

Skor $43,76 \%-62,4 \%=$ kategori kurang berperan

Skor $25,00 \%-43,75=$ kategori tidak berperan 
Prosiding Seminar Nasional Pembangunan dan Pendidikan Vokasi Pertanian

Politeknik Pembangunan Pertanian Manokwari, 31 Juli 2021

e ISSN : 2774-1982

DOI: https://doi.org/10.47687/snppvp.v2i1.174

2. Untuk menguji permasalahan yang kedua dilakukan juga dengan metode analisis deskriptif Variabel pengkajiannya adalah faktor internal (indikator: usia, pendidikan formal, pengalaman); faktor eksternal (indikator: fungsi kelompok tani, lingkungan keluarga, lingkungan masyarakat, kegiatan penyuluhan); dan minat (indikator: perasaan senang, ketertarikan, kemauan, perhatian, keterlibatan). Instrumen telah melalui uji validitas dan uji reliabilitas yang dinyatakan valid dan reliabel. Data yang diperlukan dalam pengkajian ini terdiri dari data primer (observasi, wawancara, dan kuesioner tertutup) dan data sekunder dari instansi terkait, hasil kajian terdahulu. Untuk mengukur minat petani menggunakan pengukuran skala Likert sebagai berikut:

Nilai 4: sangat berminat

Nilai 3: berminat

Nilai 2: kurang berminat

Nila 1: tidak berminat

Dalam mengukur minat anggota kelompok terhadap pengolahan pupuk organik dapat dikelompokkan sebagai berikut :

Skor tertinggi $=4$ (dengan asumsi $100 \%)$

Skor terendah $=1$ (dengan asumsi 25\%) I

Interval kelas $=$ skor tertinggi - skor terendah

Jumlah kelas

Interval kelas $=\underline{100 \%-25 \%}$

4

Interval kelas $=18,75 \% 24$

Dari interval kelas tersebut diperoleh range skor sebagai klasifikasi penilaian minat pemuda terhadap agribisnis padi sawah sebagai berikut :

Skor $81,26 \%-100 \%=$ kategori sangat berminat

Skor $62,51 \%-81,25 \%$ = kategori berminat

Skor $43,76 \%-62,5 \%=$ kategori kurang berminat

Skor $25,00 \%-43,75 \%=$ kategori tidak berminat

\section{HASIL DAN PEMBAHASAN}

\section{Hasil}

Hasil analisis data menunjukkan peran kelompok tani masuk dalam kategori berperan sebagai wahana produksi dalam mendukung pengembangan UPPO sebagai unit usaha dengan jawaban rata-rata 2,69 dengan presentase 67,33\%. Sebaran peran kelompok 
Prosiding Seminar Nasional Pembangunan dan Pendidikan Vokasi Pertanian Politeknik Pembangunan Pertanian Manokwari, 31 Juli 2021

e ISSN : 2774-1982

DOI: https://doi.org/10.47687/snppvp.v2i1.174

tani dalam mendukung pengembangan UPPO sebagai unit usaha dapat dilihat pada Tabel 1.

Tabel 1. Peran Kelompok Tani Kelompok Tani Dalam Mendukung Pengembangan UPPO Sebagai Unit Usaha

\begin{tabular}{clcc}
\hline No & \multicolumn{1}{c}{ Kategori } & Jumlah Petani & Persentase \\
\hline 1 & Sangat Berperan & 1 & $3,4 \%$ \\
2 & Berperan & 23 & $79,31 \%$ \\
3 & Kurang Berperan & 5 & $17,24 \%$ \\
4 & Tidak Berperan & 0 & $0 \%$ \\
\hline
\end{tabular}

Dilihat dari sebaran peran kelompok tani sebagai wahana produksi dalam mendukung pengembangan UPPO sebagai unit produksi diketahui bahwa jumlah petani yang paling banyak ada pada kategori berperan, ini dilihat dari jumlah petani yang mengisi sebanyak 23 orang. Sedangkan kategori lain yaitu sangat berperan sejumlah 1 petani, kurang berperan sejumlah 4 petani dan tidak berperan, tidak ada yang mengisi.

Hasil penelitian menunjukkan untuk minat petani terhadap dalam mengolah pupuk organik melalui kegiatan UPPO masuk dalam kategori minat dengan jawaban rata-rata 2,45 dengan persentase 62,79\% dengan sebaran minat petani dapat diihat pada Tabel 2 .

Tabel 2. Minat Petani dalam Mengolah Pupuk Organik

\begin{tabular}{clcc}
\hline No & \multicolumn{1}{c}{ Kategori } & Jumlah Petani & Persentase \\
\hline 1 & Sangat Minat & 1 & $3,4 \%$ \\
2 & Minat & 21 & $72,41 \%$ \\
3 & Kurang Minat & 7 & $24,13 \%$ \\
4 & Tidak Minat & 0 & $0 \%$ \\
\hline
\end{tabular}

Dilihat dari sebaran peran kelompok tani sebagai wahana produksi dalam mendukung pengembangan UPPO sebagai unit produksi diketahui bahwa jumlah petani yang paling banyak ada pada kategori minat. Ini dilihat dari jumlah petani yang mengisi sebanyak 21 orang sedangkan kategori lain yaitu sangat berminat sejumlah 1 petani, kurang berminat sejumlah 7 petani dan tidak berperan tidak ada yang mengisi.

\section{Pembahasan}

Hasil analisa dalam penelitian ini didapatkan bahwa kelompok tani berperan sebagai unit produksi dalam mengembangkan UPPO sebagai unit usaha dengan nilai ratarata 2,69 presentasenya 67,33\%. Dengan jumlah petani 23 orang yang menjawab berminat. Menurut Permentan Nomor 67 tahun 2016 sebagai unit produksi, kelompok tani diharapkan mampu mengakomodir masing-masing anggota Poktan secara keseluruhan yang merupakan satu kesatuan usaha yang dapat dikembangkan untuk mencapai skala ekonomi usaha, dengan menjaga kuantitas, kualitas dan kontinuitas. 
Prosiding Seminar Nasional Pembangunan dan Pendidikan Vokasi Pertanian

Politeknik Pembangunan Pertanian Manokwari, 31 Juli 2021

e ISSN : 2774-1982

DOI: https://doi.org/10.47687/snppvp.v2i1.174

Dalam penelitian ini diketahui juga bahwa kelompok tani seperti para pengurus juga melibatkan para anggota dalam menyusun rencana dan melaksanakan kegiatan serta mengambil keputusan untuk pengembangan UPPO sebagai suatu usahatani untuk menambah pendapatan petani. Ini sejalan dengan pendapat Handayani (2019), yang menyatakan bahwa baik secara serentak maupun parsial ada hubungan antara peran kelompok tani dengan produktivitas usahatani padi. Pratama, dkk. (2016) menyebutkan kelompok tani mempunyai peran dalam kegiatan unit produksi. Kegiatannya adalah menentukan keputusan untuk pengembangan kegiatan anggota kelompok, mengevaluasi kegiatan kelompok, melaksanakan dan mentaati kesepakatan yang telah dibuat, kegiatan pelestarian lingkungan dan menyusun laporan kegiatan kelompok. Menurut Wardani (2017) menyebutkan bahwa peranan kelompoktani sebagai unit produksi mempunyai pengaruh nyata pada produktivitas usaha tani. Secara umum lembaga poktan telah menjalankan perannya dengan baik dalam upaya peningkatan produksi pertanian dan pendapatan (Rahmadanih, dkk., 2018).

Dalam mengelola bantuan UPPO, Kelompok Tani Mekar juga melibatkan para anggota untuk ikut berpartisipasi dalam mengolah pupuk organik dengan dibuat regu piket setiap hari untuk mengolah pesanan pupuk organik dan melakukan kegiatan pertemuan untuk membahas kegiatan rutin kelompok dan kegiatan UPPO. Menurut hasil pengamatan di lapangan, penyuluh pertanian selaku pendamping juga telah melakukan bimbingan pada kelompok tani. Dengan bimbingan penyuluh pertanian, kelompok tani juga mengorganisasikan kegiatan administrasi dan penyediaan sarana prasarana produksi pertanian dengan dinas terkait sebagai syarat untuk mendapatkan bantuan UPPO dari pemerintah pada tahun 2019.

Penyuluh masih melanjutkan bimbingan setelah kelompok tani mendapatkan bantuan UPPO dalam mengelola kegiatan di lapangan. Hal ini sejalan dengan pendapat Arsyad, dkk. (2018) yang menyatakan bahwa penyuluh pertanian juga berperan dalam memberikan pengetahuan dalam bentuk bimbingan teknis untuk meningkatkan ketrampilan anggota kelompok dan mengolah pupuk organik. Hal ini sejalan dengan penelitian yang menyebutkan bahwa sikap pengambilan keputusan dalam mengaplikasikan teknologi budidaya yang didasari pengetahuan serta keterampilan yang cukup sangat menentukan peningkatan produktivitas usahatani. Hal ini membutuhkan bimbingan dan arahan agar pengetahuan, sikap dan keterampilan para petani lebih meningkat mengikuti perkembangan teknologi yang selalu berubah. 
Prosiding Seminar Nasional Pembangunan dan Pendidikan Vokasi Pertanian

Politeknik Pembangunan Pertanian Manokwari, 31 Juli 2021

e ISSN : 2774-1982

DOI: https://doi.org/10.47687/snppvp.v2i1.174

Produksi usaha tani dapat dipengaruhi peranan kelompoktani sebagai unit produksi. Adanya pengaruh peranan kelompok tani sebagai unit produksi sesuai penelitiannya Douthwaite et al. (2006), Hellin et al. (2009), Ofuoku dan Isife (2009) dan Chesoli (2013). Bahwa produksi dan unit usaha tani (produksi) perannya adalah cukup baik. Ini juga sejalan dengan pendapat Wardani dan Anwarudin (2018) yang menyatakan bahwa penyuluh pertanian dapat membantu dalam penguatan kelompoktani dimana penyuluh pertanian dapat membantu mengaktifkan fungsi kelompok tani.

Dalam penelitian ini juga diketahui bahwa kelompok tani sudah berperan dalam menjalin kerjasama di bidang pemasaran pupuk organik tetapi masih di lingkup Kabupaten Sleman dan Kota Yogyakarta. Lokasi mereka membeli pupuk organik dengan cara memesan melalui media sosial seperti whatsapp maupun datang langsung ke kandang kelompok. Dalam hal ini kelompok juga ternyata masih belum menjalin kerjasama dengan pihak lain seperti penyedia sarana dan prasarana produksi pertanian seperti pabrik, kios saprotan maupun pihak perbankan sebagai mitra.

Minat individu sangat dipengaruhi oleh persepsi individu yang bersangkutan, karena dengan persepsi individu dapat menyadari dan mengerti tentang keadaan lingkungannya serta keadaan diri individu yang bersangkutan. Sehingga dengan begitu individu dapat memutuskan perilaku atau reaksi apa yang harus dilakukannya dalam hal ini berupa minat (Rahma, dkk., 2020) Dalam penelitian ini, didapatkan hasil bahwa petani berminat dalam mengolah pupuk organik dengan nilai rata-rata 2,51 dan persentasenya $62,79 \%$ jumlah petani 21. Petani berminat mengolah pupuk organik dalam kegiatan UPPO karena mereka merasa mempunyai tanggung jawab untuk berperan aktif dalam kegiatan UPPO agar dapat lebih berkembang lagi dari sekarang. Dari sisi pemasaran, baru ada beberapa pihak luar seperti dari Kabupaten Bantul dan Kota Yogyakarta yang memesan dan membeli pupuk organik di UPPO Kelompok Tani Mekar, baik yang kasar maupun yang halus.

Minat petani juga didukung oleh pengalaman dalam mengolah pupuk organik dan jumlah kepemilikan ternak sapi. Khoir, dkk. (2020) dalam penelitiannya menyebutkan bahwa salah satu dari faktor internal yang mempengaruhi minat petani terhadap penggunaan biourine sebagai pupuk organik cair pada tanaman bawang merah adalah pengalaman berusahatani diperoleh nilai signifikansi $0,029<0,05$ yang artinya terdapat pengaruh nyata. Kepemilikan sapi dalam penelitian ini bervariasi antara 1-3 ekor. Sapisapi mereka rata-rata perhari menghasilkan kotoran 5-10 kg per ekor yang dapat digunakan 
Prosiding Seminar Nasional Pembangunan dan Pendidikan Vokasi Pertanian

Politeknik Pembangunan Pertanian Manokwari, 31 Juli 2021

e ISSN : 2774-1982

DOI: https://doi.org/10.47687/snppvp.v2i1.174

sebagai bahan baku pupuk organik. Usia petani sebagai responden berusia di atas 50 tahun sebanyak 48,27\% tahun dan usia 40-50 tahun sebanyak 51,73\%. Mereka juga rata-rata sudah berpengalaman dalam melakukan usaha tani padi lebih dari 15 tahun. Petani juga mempunyai ternak sapi dan berpengalaman dalam mengolah limbah ternak sebagai pupuk organik. Pengalaman ini juga yang menjadi salah satu alasan petani untuk melibatkan diri dalam kegiatan pengolahan pupuk organik. Hulyatussyamsiah, dkk., (2019) dalam penelitiannya menyebutkan bahwa luas lahan dan pendapatan sangat mempengaruhi minat petani dalam mengolah pupuk, sedangkan bantuan dan pengalaman mempunyai pengaruh nyata terhadap minat organik dengan bahan baku dari limbah sapi.

Rata-rata kepemilikan lahan petani dalam penelitian ini adalah $2.000 \mathrm{~m}^{2}$ yang ditanami padi dan palawiija. Kepemilikan lahan tersebut hanya seperlima hektar dan termasuk kategori sempit sesuai dengan laporan Anwarudin, dkk (2020). Kepemilikan lahan mempengaruhi pendapatan petani. Pendapatan para petani memang tidak rutin setiap bulannya mereka hanya mengandalkan pendapatan dari hasil panen padi dan palawija. Bagi petani yang mempunyai ternak akan menjual sapinya jika membutuhkan uang dengan segera.

Petani juga menyadari bahwa dengan keterlibatan mereka dalam pengolahan pupuk organik akan dapat memberikan keuntungan tambahan. Hal inilah yang membuat mereka berminat untuk ikut terlibat mengelola produksi pupuk organik dalam kegiatan UPPO di kelompok. Dalam bidang pemasaran pupuk organik, ada beberapa petani yang kurang berminat. Ini dikarenakan mereka merasa tidak mempunyai kemampuan dalam memasarkan produk pupuk organik, di satu sisi mereka juga tidak mempunyai waktu yang cukup untuk membantu pemasaran pupuk organik kelompok karena mereka sibuk di sawah. Kelompok tani dalam mengusahakan kegiatan mengolah pupuk organik juga mendapat dukungan dari masyarakat yang ada sekitarnya, ini bisa dilihat dari beberapa anggota masyarakat sekitar yang tidak menjadi anggota kelompok tapi mau menitipkan ternak sapinya di kandang kelompok dan dimana kotoran sapinya dimanfaatkan sebagai bahan baku untuk memproduksi pupuk organik. Dukungan masyarakat sekitar ini jugalah yang menjadi salah satu unsur penambah semangat dan minat petani untuk lebih aktif berperan dalam pengolahan pupuk organik.

Dari sisi pendidikan, rata-rata petani responden berpendidikan dasar dan menengah. Kondisi ini sejalan dengan laporan Anggini, dkk. (2019) dan Apriliya, dkk. (2020) bahwa pendidikan petani mayoritas berpendidikan Sekolah Dasar. Walaupun 
Prosiding Seminar Nasional Pembangunan dan Pendidikan Vokasi Pertanian

Politeknik Pembangunan Pertanian Manokwari, 31 Juli 2021

e ISSN : 2774-1982

DOI: https://doi.org/10.47687/snppvp.v2i1.174

demikian mereka masih aktif terlibat sesuai dengan kesepakatan yang sudah dibuat dan disepakati bersama-sama yaitu piket setiap hari secara bergantian untuk menjaga sapi dan mengolah pupuk organik di kandang kelompok. Ini karena mereka merasa ikut bertanggung jawab mengelola bantuan UPPO yang telah diterima. Menurut Oktaviani, dkk. (2017), satu dari dua faktor internal yaitu faktor pendapatan berpengaruh terhadap minat petani, kemudian faktor eksternal yaitu terdiri dari faktor lingkungan keluarga dan lingkungan masyarakat juga berpengaruh terhadap minat petani. Faktor pendidikan tidak berpengaruh terhadap minat petani. Wuri, dkk. (2021) dalam penelitiannya juga menyebutkan bahwa pendidikan mempunyai pengaruh tidak nyata terhadap minat.

\section{KESIMPULAN DAN SARAN}

\section{Kesimpulan}

Berdasarkan dari hasil analisis data dan pembahasan dapat disimpulkan bahwa peran kelompok tani sebagai wahana produksi dalam rangka mendukung produksi pengolahan pupuk oganik masuk dalam kategori berperan dengan nilai rata-rata 67,33 walaupun dari sisi kerjasama kemitraan dan kegiatan pemasaran yang lebih luas masih harus ditingkatkan. Dalam mengolah pupuk organik melalui kegiatan UPPO, petani masuk kategori berminat dengan nilai rata-rata $62,79 \%$.

\section{Saran}

Untuk dapat lebih meningkatkan peran kelompok tani, dapat dilakukan dengan kegiatan pendampingan dari pembina untuk menjalin kerjasama kemitraan dengan pihak lain dalam bidang pemasaran pupuk organik sehingga UPPO sebagai suatu unit produksi pupuk organik dapat berkembang sebagai suatu usaha produktif.

\section{DAFTAR PUSTAKA}

Anggini, D., Hartono, R., \& Anwarudin, O. (2019) Perilaku petani dalam pemanfaatan limbah sayuran sebagai pupuk bokashi pada tanaman sawi putih, Jurnal Triton, 10(1), 99-115.

Anwarudin, O., Sumardjo, S., Satria, A., \& Fatchiya, A. (2020) Proses dan pendekatan regenerasi petani melalui multistrategi di Indonesia, Jurnal Penelitian dan Pengembangan Pertanian. 39(2), 73-85.

Apriliya, D., Anwarudin, O., \& Nazaruddin, N. (2020) Diseminasi Teknologi Asam Humat pada Budidaya Padi Sawah di Kecamatan Palimanan Kabupaten Cirebon, Jurnal Inovasi Penelitian (JIP), 1(3), 337-346.

Arsyad, M. (2018) Role of Joined Farmer Group in Enhancing Production and Farmers Income. IOP Conference Series Earth and d Environmental Science, May 2018, 17. 
Prosiding Seminar Nasional Pembangunan dan Pendidikan Vokasi Pertanian

Politeknik Pembangunan Pertanian Manokwari, 31 Juli 2021

e ISSN : 2774-1982

DOI: https://doi.org/10.47687/snppvp.v2i1.174

Chesoli, C. W. (2013) Types of Capacity Building Activities for Improved Market Participation by Farmer Groups in Turbo, Kenya, Journal of Emerging Trends in Economics and Management Sciences (JETEMS), 4(4), 377-380.

Douthwaite, B., Carvajal, A., Alvarez, S., Claros, E., \& Hernández, L. A. (2006) Building farmers' capacities for networking (Part I): Strengthening Rural Groups in Colombia Through Network Analysis, KM4D Journal, 2(2), 4-18.

Handayani, W. A. (2019) Peran Kelompok Tani Dalam Meningkatkan Poduktivitas Usahatani Padi, Jurnal AGRISTAN, 1(2), 80-88.

Helin, J. (2007) Farmer Organization, Collective Action and Market Access in MesoAmerica. CaPRi Working Paper, 67(2007), 1-25.

Hulyatussyamsiah, S. N., Hartono, R., Anwarudin, O. (2019) Adopsi pemupukan berimbang padi sawah melalui penggunaan urea berlapis arang aktif di Majalengka. Jurnal Penyuluhan Pertanian. 14(2), 1-17.

Kementerian Pertanian. (2015) Pedoman Teknis Pengembangan Unit Pengolah Pupuk Oganik (UPPO).

Kementerian Pertanian. (2016) Peraturan Menteri Pertanan Nomor 67/ Permentan/SM.050/12/2016 Tentang Pembinaan Kelembagaan Petani.

Khoir, A. M. (2020) Minat Petani Terhadap Penggunaan Biourine Sebagai Pupuk Organik Cair Pada Tanaman Bawang Merah (Allium ascolinicum.L) di Kecamatan Tarumajaya Kabupaten Bekasi. Jurnal Inovasi Pertanian (JIP), 1(4), 791-798.

Mosher, A.T. (1985) Getting Agriculture Moving. Diterjemahkan oleh Krisnandhi dan B. Samad. Menggerakkan dan Membangun Pertanian.

Oktaviani, L. (2017) Analisis Pendapatan dan Faktor-Faktor Yang Mempengaruhi Minat Petani Terhadap Usahatani Sawah di Kecamatan Meureubo Kabupaten Aceh Barat. Jurnal Ilmiah Mahasiswa Pertanian Unsyiah, 2(1), 191-199.

Ofuoku, A. U., \& Isife, B. I. (2009) Causes, Effect and Resolution of Farmers-nomadic Cattle Herders Conflict in Delta State, Nigeria, International Journal of Sosiology and Anthropology, 1(2), 47-54.

Pratama, B. P. (2016) Peran Kelompok Tani Dalam Meningkatkan Pendapatan Petani Swadaya Kelapa Sawit di Desa Bukit Lingkar Kecamatan Batang Cenaku Kabupaten Indragiri Hulu. Jom Faperta, 3(2),1-12.

Rahma, D. A. (2020) Hubungan Persepsi Petani Terhadap Pembentukan Kelompok Tani Dengan Minat Berkelompok, Jurnal Agristan, 2(2), 121-132.

Rahmadanih. (2018) Role of Farmer Group Institutions in Increasing Farm Production and Household Food Security. IOP Conference Series: Earth and Environmental Science 157(2018), 1-7.

Sardjono, N. (2012) Strategi Pengembangan Siste Produksi Pupuk Organik pada Unit pengolahan Pupuk Orgaik (UPPO) di Desa Bangunsari Kabupaten Ciamis. Jurnal Teknologi Pertanian, 13(2), 138-148.

Sugiyono. (2009) Metode Penelitian Kuantitatif, Kualitatif dan R \& D. Bandung: Alfabeta.

Supriyanto. (2010) Metodologi Riset: Manajemen Sumberdaya Manusia, Malang: UINMaliki Press. 
Prosiding Seminar Nasional Pembangunan dan Pendidikan Vokasi Pertanian

Politeknik Pembangunan Pertanian Manokwari, 31 Juli 2021

e ISSN : 2774-1982

DOI: https://doi.org/10.47687/snppvp.v2i1.174

Wardani. (2017) Peranan Kelompok Tani Dalam Meningkatkan Produktivitas Usaha Tani (Kasus Di Wilayah BP3K Sukalarang, Sukabumi), Jurnal Penyuluhan Pertanian, 12(1).

Wardani \& Anwarudin, O. (2018) Peran Penyuluh terhadap Penguatan Kelompok Tani dan Regenerasi Petani di Kabupaten Bogor Jawa Barat. Journal TABARO Agriculture Science, 2(1), 191-200.

Wuri, N., Sugihardjo, Wibowo, A. (2021) Faktor yang Mempengaruhi Partisipasi Petani dalam Kegiatan Pengolahan Pupuk Organik di Desa Banjaratma, Kecamatan Bulakamba, Kabupaten Brebes. Jurnal Triton, 12(1), 89-97. 